\title{
Biodiversity in a Cool-Climate Vineyard: A Case Study from Quebec
}

\author{
Charles Vincent ${ }^{1}$, Jacques Lasnier ${ }^{2, *}$, Charles-Henri de Coussergues ${ }^{3}$ and Alain Baril ${ }^{4}$ \\ 1 Saint-Jean-Sur-Richelieu Research and Development Center, Agriculture and Agri-Food Canada, \\ 430 Gouin Blvd., Saint-Jean-Sur-Richelieu, QC J3B 3E6, Canada; ch20100@yahoo.ca \\ 2 Co-Lab R\&D Division d'Ag-Cord Inc., 655 Delorme St., Granby, QC J2J 2H4, Canada \\ 3 Vignoble de L'Orpailleur, 1086 Bruce St., Dunham, QC J0E 1M0, Canada; charles-henri@orpailleur.ca \\ 4 Plant Select, 1190 Principale West St., St.-Paul-d'Abbotsford, QC J0E 1A0, Canada; alainbaril@plantselect.ca \\ * Correspondence: jlasnier@translog.ca; Tel.: +1-450-830-5554
}

Citation: Vincent, C.; Lasnier, J.; de Coussergues, C.-H.; Baril, A.

Biodiversity in a Cool-Climate

Vineyard: A Case Study from Quebec. Insects 2021, 12, 750. https://doi.org/ $10.3390 /$ insects 12080750

Academic Editors: Daniele

Sommaggio, David G. James and Giovanni Burgio

Received: 30 June 2021

Accepted: 16 August 2021

Published: 19 August 2021

Publisher's Note: MDPI stays neutral with regard to jurisdictional claims in published maps and institutional affiliations.

Simple Summary: This paper documents research activities related to the biodiversity of the l'Orpailleur vineyard located in Dunham (Quebec, Canada) from 1997 to 2021. In a first phase starting in 1997, the biodiversity of insecticide-free and insecticide-treated parts of the vineyard was determined for several taxa. In a second phase starting 2004, entomological problems were addressed on an ad hoc basis as they unfolded. For example, at the request of viticulturists, research was conducted on the tarnished plant bug (Lygus lineolaris-Miridae) and on the system phytoplasmas/cicadellids/grapevines. In a third phase starting in 2014, management of plants between grapevine rows and areas adjacent to the vineyard was carried out to increase biodiversity with the aim to achieve arthropod control with minimal insecticide and acaricide use. To address the advent of a new pest, such as the Japanese beetle (Popillia japonica-Scarabaeidae), a biocontrol program based on the parasite Istocheta aldrichi (Tachinidae) was initiated.

Abstract: In Quebec (Canada), viticulture has experienced steady growth in the last 35 years in terms of surfaces cultivated and value, although it is practiced in climatic conditions at the edge of what is considered a cool-climate area. This case study documents biodiversity studies conducted at the l'Orpailleur vineyard (Dunham, QC, Canada) from 1997 to 2021. In a first phase starting in 1997, the biodiversity of insecticide-free and insecticide-treated plots was determined for the taxa Scarabaeidae, Curculionidae, Chrysomelidae, Cicadellidae, Acari and Aranae. This step provided a baseline allowing to identify key arthropods. In a second phase starting in 2004, entomological issues were addressed on an ad hoc basis. In 2014, a third phase began with a perspective of sustainability and management of plant diversity in the vineyard to conserve natural enemies. Because of increased Japanese beetle (Popillia japonica-Scarabaeidae) populations and threats to vineyards, a biocontrol program based on the parasitoid Istocheta aldrichi (Tachinidae) was initiated. The unusually fast development of grapevines during the growing season, selection of flowering species, as well as selected arthropods associated with these flowering species, will be illustrated. Periodic update of protection programs will be required to address future challenges associated with climate change scenarios and world trade.

Keywords: arthropod; invasive insect species; cool-climate viticulture; grapevine; nectariferous plants; sustainability; agro-ecology

\section{Introduction}

Since antiquity, grape cultivation (i.e., viticulture) and wine making (i.e., oenology) have been practiced in regions near the Mediterranean Sea and in Transcaucasia where grape originated (Vitis vinifera-Vitaceae) [1,2]. From the antiquity to the mid-70's, grape and wine production was mostly led by European countries. Since then, viticulture and oenology experienced worldwide robust and steady growth in terms of surfaces under 
cultivation and dollar value [3]. New regions, notably North America (USA, Canada), South America (Argentina, Chile), South Africa, Australia, New Zealand and, more recently, China, developed their viticultural and oenological industries. As of 2019, table wine and dried grapes were cultivated on 7.4 million ha worldwide [4]. About $50 \%$ of grapecultivated areas are found in Spain, China, France, Italy, and Turkey. Meanwhile, the number of wine consumers have rapidly increased, as well as their eagerness for more quality wine.

In various parts of the world, for example in California [5], viticulture has been mostly practiced as a monoculture until the 1990s. However, several factors have since been driving viticulture towards more sustainable practices [3], notably: (1) worldwide trade and competition, (2) climate change that may cause water shortage in some major grapeproducing areas (e.g., [6-8]), (3) climate change that may exacerbate invasive species that challenge existing protection programs, and (4) consumer appeal for products based on sustainable practices.

Sustainability is a concept that can be considered in several ways depending on region, agronomic situation, and market $[9,10]$. Some viticulturists embrace the sustainability concept to differentiate their organization because consumers see increased value in the way vineyards are managed. This approach can be based on economic (decrease costs), marketing (enhanced value perceived by consumers) or environmental (less pesticide input) considerations [9].

From an agroecology perspective, the idea of managing biodiversity to enhance ecological services has recently arisen [11-14]. In vineyards, the management of plant biodiversity can provide services and disservices affecting several agronomic parameters, notably soil fertility, health, carbon and $\mathrm{N}$ balance (input vs. uptake), soil erosion, competition with weeds, water management, and grape yield reduction [15].

Plant biodiversity can also impact arthropod biodiversity of vineyards, as documented in the last decade in several European studies. For example, ground cover plant management (i.e., Sweet Alyssum, Phacelia, Buckwheat, Faba Bean, Vetch and Oat) in vineyards of Northern Italy significantly affected the arthropod fauna, including beneficial groups providing ecosystem services, such as biological control of arthropod pests [16]. Phytoseiid predatory mites (Typhlodromus pyri, Kampimodromus aberrans, Paraseiulus soleiger, Euseius finlandicus) were shown to be more abundant on leaves of the vineyard plots with ground covers than in the control. Also in Northern Italy, the abundance of key natural enemies, notably predatory mites (K. aberrans, Amblyseius andersoni, T. pyri, Phytoseius finitimus), parasitic wasps, spiders, and some grapevine leafhoppers (Zygina rhamni) increased when the frequency of grass mowing was reduced [17].

In France, the abundance of six pest species, including Panonychus ulmi (Tetranychidae) and Scaphoideus titanus (Cicadellidae), and the beneficial mite Orthotydeus lambi (Tydeidae), was lower in vineyards with cover crops, while the abundance of the predatory mite T. pyri (Phytoseiidae) was higher in plots with cover crops [18]. Cover crops did not impact the intensity of diseases (Plasmopara viticola, Uncinula necator and Guignardia bidwellii).

In Austria, a study conducted in 32 organic and integrated vineyards concluded that predatory mites (T. pyri $=98.7 \%$; Euseius finlandicus $=0.65 \%$; Paraseiulus talbii $=0.62 \%$ ) benefited from spontaneous vegetation cover in vineyard inter-rows and less intensive pesticide use [19].

In Romania, a study in 16 vineyards concluded that management intensity affected the diversity of some plant species and some invertebrate groups, but found the overall effect to be ambiguous [20].

In California, management of resident vegetation inside the vineyards and vegetation surrounding the vineyards is considered as complementary measures [5]. Summer cover crops grown inside vineyards substantially enhanced biological control of leafhoppers (Erythroneura elegantula) and thrips (Franklinella occidentalis) [5].

There is a paucity of publications on biodiversity of arthropods associated with vineyards conducted in cool-climate conditions, as well as on deliberate use of plants to 
manage these arthropod pests. This case study focuses on arthropod and plant biodiversity at the $1^{\prime}$ Orpailleur vineyard (Figure 1A). Located in Dunham $\left(45^{\circ} 07^{\prime} 05^{\prime \prime} \mathrm{N}-72^{\circ} 49^{\prime} 16^{\prime \prime} \mathrm{W}\right)$, Quebec, Canada, l'Orpailleur is a vineyard where we conducted studies from 1997 to 2021 in three phases. In a first phase (1997-2003), briefly reviewed here, studies allowed for documentation of arthropod biodiversity and to identify key pests. In a second phase (20042013), entomological problems posed by established species were addressed as they arose. In a third phase (2014-2021), management of established arthropod pests was attempted by increasing biodiversity of vegetation in a context where the growing season is short and winters are very cold. The advent of invasive insects was addressed on a per case basis.
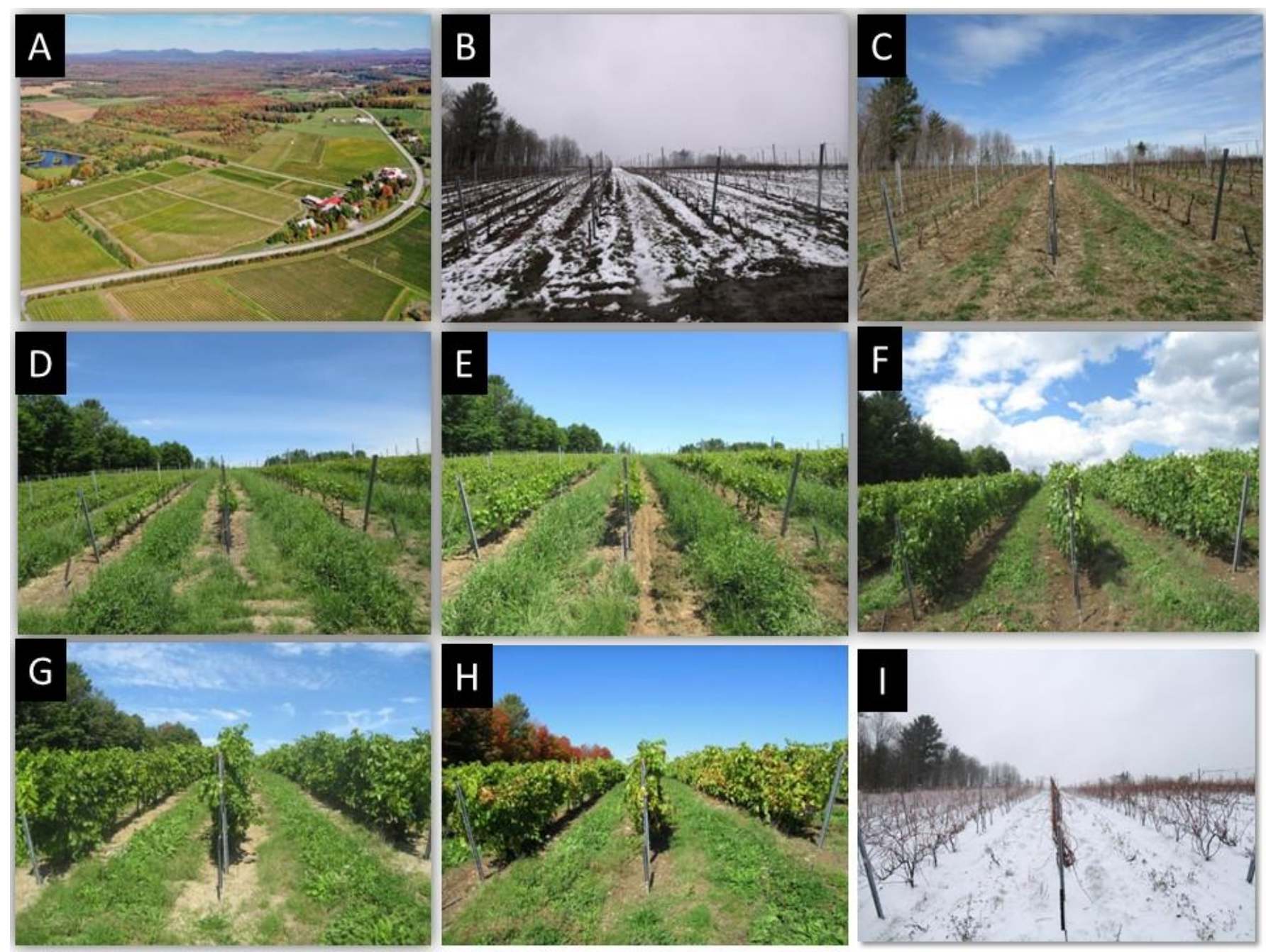

Figure 1. (A) Aerial view of the l'Orpailleur vineyard (Dunham, QC, Canada) and surrounding landscape. From (B-I): Development of vegetation deliberately established between rows of vines at the Bellevue site of the l'Orpailleur vineyard. (B) 11 April 2020; (C) 30 April 2020; (D) 30 May 2020; (E) 30 June 2020; (F) 31 July 2020; (G) 31 August 2020; (H) 30 September 2020; (I) 2 November 2020.

Viticulture in Quebec. In Quebec, grape cultivation is practiced in meteorological conditions at the edge of cool-climate viticulture such that winter survival of grapevines is a major limiting factor. In winter, air temperatures frequently reach $-30{ }^{\circ} \mathrm{C}$ and, occasionally, $-35^{\circ} \mathrm{C}$. Grape cultivars may be assigned to three categories of rusticity: rustic cultivars can withstand $-25{ }^{\circ} \mathrm{C}$ to $-30{ }^{\circ} \mathrm{C}$; semi-rustic cultivars, $-20^{\circ}$ to $-24{ }^{\circ} \mathrm{C}$; and sensitive cultivars, $-17^{\circ} \mathrm{C}$ to $-19^{\circ} \mathrm{C}$. Rustic cultivars do not need winter protection. To protect semi-rustic and sensitive cultivars, some Quebec viticulturists hill vines with soil in late fall and unhill them in spring, or cover vines with geotextiles in the fall (see Figure 1 in [21]). 
Vine parts under snow cover are protected from harsh low temperatures. For example, in Frelighsburg, QC, when air temperatures hovered around $-22{ }^{\circ} \mathrm{C}$ for several days in winter, soil temperatures at $3 \mathrm{~cm}$ seldom reached $-5^{\circ} \mathrm{C}$ [22]. The most striking method to cope with harsh winter conditions has been the use of geothermal energy (thanks to $15,000 \mathrm{~m}$ of tubes buried $2 \mathrm{~m}$ in the soil) to manage temperatures of vines grown under tunnels, as practiced in a winery located in Dunham, QC [23].

The season of vegetation in Quebec is short and of variable duration. In 2020, there was snow on 11 April on the soil at the l'Orpailleur vineyard (Figure 1B) and, in the fall, on 2 November (Figure 1I). Depending on prevailing spring temperatures, the woolly bud stage (B-Baggiolini; 03 Eichhorn-Lorenz) of grapevines has been observed from 27 April in 2009 to 19 May in 2020 (Table 1) [24]. On average, from 2009-2020 134 days were required to progress from the woolly bud stage to the berry ripe stage (N 38), i.e., beginning of harvest. The shortest and longest period were respectively 110 (2020) and 162 days (2010) on cultivar Seyval blanc in Dunham, QC (Table 1). These cool-climate conditions allow the production of specialty wines, such as Icewine and Vendanges tardives. Overall, the demand for Quebec wines is much higher than current wine production $(\mathrm{C}-\mathrm{H}$. de Coussergues, pers. comm.).

Finally, the size of vineyards (in ha) matters. While l'Orpailleur vineyard totals 37 ha of non- contiguous plots in production, the average surface in production of leading vineyards in Quebec is 11 ha [25], such that the proximity between cultivated vines and other plant species allows movement of arthropods from one plant species to another, and from plants growing outside the vineyards, but immediately adjacent to the cultivated vines.

Arthropod biodiversity in two insecticide-free vineyards. Starting in 1997, research projects were conducted on the biodiversity of arthropods in insecticide-free plots of two vineyards located in southern Quebec, notably l'Orpailleur and the Vineyard Dietrich-Jooss located in Iberville $\left(45^{\circ} 15^{\prime} 26^{\prime \prime} \mathrm{N}-73^{\circ} 9^{\prime} 30^{\prime \prime} \mathrm{W}\right)$, Qc. This led to a number of scientific publications on the biodiversity of phytophagous arthropods [22,26-28]; Carabidae (124 species in Quebec vineyards); Cicadellidae (110 species [26,29]); Aranae (97 species); Curculionidae (73 species); Coccinellidae (22 species [30]); and Chrysomelidae (59 species). As stated by Kreiter [31], these publications, reviewed by Vincent et al. [28], constitute baselines that are unique contributions to the study of arthropod diversity in minimally managed vineyards. Thanks to the first phase, we identified key arthropods of vineyards in Southern Quebec.

As Dietrich-Jooss vineyard phased out its operations in 2004, we focused our research efforts on the l'Orpailleur vineyard. As the Quebec viticultural industry developed and the research studies unfolded, specific arthropod issues, such as the tarnished plant bug (Lygus lineolaris- Miridae), were addressed on an ad hoc basis [32,33]. L. lineolaris feeds on ca. 398 host plants and is highly mobile in vineyards [33]. Hence, it is a pest of great concern. Meanwhile, studies on the arthropod fauna associated with floral strips cultivated between rows of apple trees were conducted at the experimental farm of Agriculture and Agri-Food Canada located at Frelighsburg, QC [34]. They demonstrated the attractiveness of floral strips (Tanacetum vulgare, Chrysanthemum maximum, Aster tongolensis, Achillea millefolium; all Asteraceae) towards natural enemies, notably hymenopterans (Ichneumonoidea, Chalcidoidae, and Proctotrupoidea) and dipterans (Cynipoidea, Syrphidae, and Tachinidae) species [35].

Managing plant and arthropod biodiversity in Quebec vineyards. Before the advent of cultivated vines in the 17th century, there were wild vines in Quebec [36]. False Virginia creeper (Parthenocissus vitacea) and riverbank grape (Vitis riparia) are vine species native to Quebec, and Virginia creeper (Parthenocissus quinquefolia) is an introduced species [37]. If these plant species are left unmanaged in areas adjacent to the vineyards, they may harbor arthropod pests of cultivated vines as well as beneficials. 
Table 1. Date of occurrence of phenological stages of grapevines (cultivar Seyval) grown at the l'Orpailleur vineyard (Dunham, QC) from 2009 to 2020.

\begin{tabular}{|c|c|c|c|c|c|c|c|c|c|c|c|c|c|}
\hline $\begin{array}{l}\text { Phenological Stage } \\
\text { (Baggiolini } \\
\text { Eichhorn-Lorenz) }\end{array}$ & $\begin{array}{c}\text { Day Degrees } \\
\left(>10^{\circ} \mathrm{C}\right) \\
\text { Starting } 1 \text { April }\end{array}$ & 2009 & 2010 & 2011 & 2012 & 2013 & 2014 & 2015 & 2016 & 2017 & 2018 & 2019 & 2020 \\
\hline Woolly bud (B 03) & 25 & 27 April & 5 April & 2 May & 2 May & 30 April & 9 May & 4 May & 12 May & 27 April & 3 May & 10 May & 19 May \\
\hline Bud swell (C 05) & 48 & 7 May & 1 May & 13 May & 13 May & 2 May & 13 May & 6 May & 19 May & 6 May & 8 May & 23 may & 21 May \\
\hline Green shoot (D 06) & 56 & 9 May & 3 May & 18 May & 15 May & 4 May & 14 May & 8 May & 21 May & 13 May & 10 May & 25 may & 23 May \\
\hline $\begin{array}{l}2 \text { to } 3 \text { leaves } \\
\text { unfolded (E 09) }\end{array}$ & 75 & 20 May & 6 May & 20 May & 19 May & 6 May & 16 may & 9 May & 23 May & 17 May & 16 May & 30 May & 26 May \\
\hline $\begin{array}{c}\text { Inflorescences } \\
\text { clearly visible (F 12) }\end{array}$ & 125 & 6 June & 23 May & 28 May & 24 May & 11 May & 29 May & 18 May & 28 May & 28 May & 26 May & 10 June & 29 May \\
\hline $\begin{array}{l}\text { Single flowers in } \\
\text { compact groups } \\
\text { (G 15) }\end{array}$ & 145 & 11 June & 25 May & 30 May & 26 May & 20 May & 02 June & 24 May & 30 May & 31 May & 29 May & 13 June & 4 June \\
\hline $\begin{array}{c}\text { Flowers separating } \\
(\mathrm{H} \mathrm{17})\end{array}$ & 170 & 14 June & 27 May & 1 June & 29 May & 23 May & 04 June & 27 May & 1 June & 8 June & 31 May & 17 June & 6 June \\
\hline $50 \%$ Flowering (I 23) & 315 & 30 June & 19 June & 21 June & 19 June & 19 June & 23 June & 19 June & 21 June & 23 June & 21 June & 2 July & 22 June \\
\hline $50 \%$ Fruit set (J 27) & 375 & 7 July & 25 June & 27 June & 24 June & 25 June & 29 June & 25 June & 27 June & 30 June & 29 June & 6 July & 27 June \\
\hline $\begin{array}{l}\text { Beginning of harvest } \\
\text { (N 38) }\end{array}$ & & $\begin{array}{c}22 \\
\text { September }\end{array}$ & $\begin{array}{c}15 \\
\text { September }\end{array}$ & $\begin{array}{c}13 \\
\text { September }\end{array}$ & $\begin{array}{c}11 \\
\text { September }\end{array}$ & $\begin{array}{c}16 \\
\text { September }\end{array}$ & $\begin{array}{c}15 \\
\text { September }\end{array}$ & $\begin{array}{c}15 \\
\text { September }\end{array}$ & $\begin{array}{c}13 \\
\text { September }\end{array}$ & $\begin{array}{c}18 \\
\text { September }\end{array}$ & $\begin{array}{c}9 \\
\text { September }\end{array}$ & $\begin{array}{c}17 \\
\text { September }\end{array}$ & $\begin{array}{c}7 \\
\text { September }\end{array}$ \\
\hline $\begin{array}{c}\text { Day Degrees } \\
\left(>10^{\circ} \mathrm{C}\right) \text { at } \\
\text { beginning of harvest }\end{array}$ & & 1036 & 1211 & 1185 & 1217 & 1169 & 1107 & 1216 & 1211 & 1087 & 1249 & 1072 & 1184 \\
\hline $\begin{array}{l}\text { No. Days between } \\
\text { Woolly bud (B 03) } \\
\text { and beginning of } \\
\text { harvest (N 38) }\end{array}$ & & 147 & 162 & 133 & 131 & 138 & 128 & 133 & 123 & 143 & 128 & 129 & 110 \\
\hline
\end{tabular}

* In parentheses, letters and numbers refer respectively to the Baggiolini and Eichhorn-Lorenz phenological systems [24]. 
As viticulture developed in Quebec, preventive and sustainable methods to manage most arthropod pests (Table 2 in [38]; Table 1 in [21]) were increasingly needed. To that end, innovative approaches have been documented in other grape-producing areas, notably in Australasian [39] and Californian [40] vineyards. In these examples, several ecosystem services (e.g., biodiversity conservation, biological control, nutrient management, erosion control, weed suppression) were enhanced by managing the floor vegetation between and on vine rows. In New Zealand, buckwheat (Fagopyrum esculentum- Polygonaceae) sown between vine rows enhanced several services, notably providing nectar resources to natural enemies. Wilson and Daane [41] reported that planting flowering cover crops (i.e., buckwheat (F. esculentum), sweet alyssum (Lobularia maritima), purple tansy (Phacelia tanacetifolia), and clovers (Trifolium spp.) in summer is relatively rare in California, primarily because these plants compete with water, which is a limiting resource. This conclusion is irrelevant for Quebec vineyards, where water is not a limiting factor because of abundant rainfall throughout the growing season. Clearly, the management of plant diversity must be tailored for a given viticultural region: different terroirs mean different biodiversities.

By favouring a diversity of spontaneous or sown plant species in and areas adjacent to cultivated vines (Figure 2A-I), we aimed to increase nectar resources and refuges, and thereby populations of natural enemies throughout the season. The choice of winter protection of vines may influence cover vegetation and, thus, phytosanitary practices. In semi-rustic and vinifera cultivars covered with geotextiles and uncovered rustic cultivars, establishment of soil cover by spontaneous vegetation, i.e., native or non-native plants issued from seed banks and rhizomes in the soil, was achieved. However, hilling/unhilling grapevines precluded the establishment of a permanent cover vegetation on and between grapevine rows.

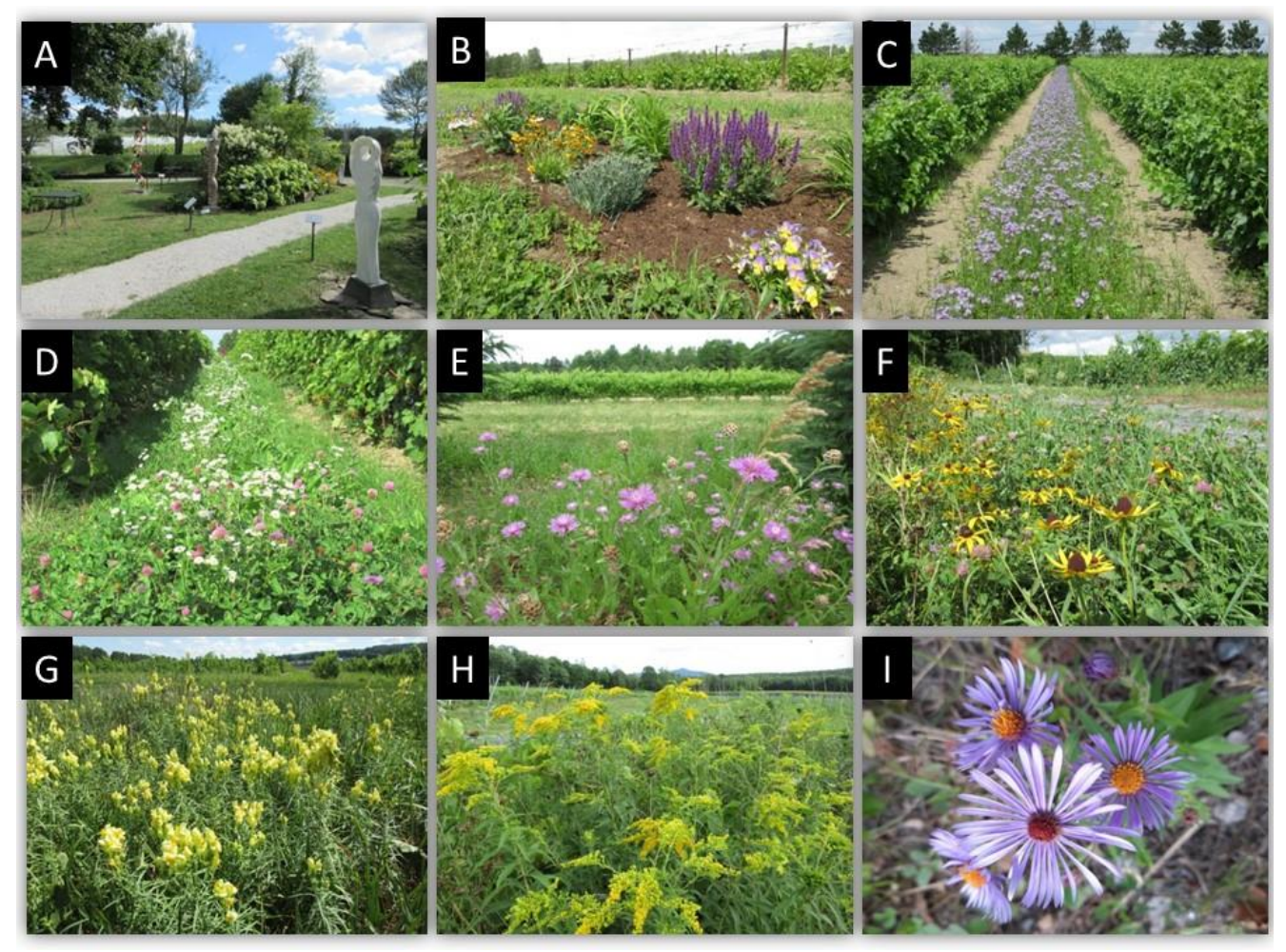

Figure 2. (A) Sculpture and vegetation established between the buildings of the winery and the vineyard (in background) for aesthetic purpose (Dunham, QC); (B) Vegetation established in the vineyard (in background) for aesthetic purpose; (C) Phacelia sp. (in flower) planted between vine rows to increase floral resources. Destroyed by hilling in the fall, they are re-sown in spring; (D) Wild Aster sp., Centaurea sp. and Trifolium sp. plants established for several years between vine rows. These plants are mown twice per season; (E) Wild flowers Centaurea vochinensis (short-fringed knapweed); (F) Wild Rudbeckia latiniata (cut-leaved coneflower); (G) Linaria vulgaris (yellow toadflax); (H) Solidago canadensis (Canada goldenrod); (I) Aster patens (late purple aster). See Table 2A for flowering times of (E-I). 
Table 2. (A) Most common species of spontaneous flowering plants established in all plots between rows in the vineyard and in strips adjacent to the vineyard from April (Ap.) to October (Oc.). (B) Plants sown between rows of hilled/unhilled vines. In a given month, the intensity of the color is proportional to the abundance of floral resources.

\begin{tabular}{|c|c|c|c|c|c|c|c|c|c|c|}
\hline Family & Latin Name (Figure No.) & \# sp. & Common Name & Ap & Ma & $\mathrm{Ju}$ & $\mathrm{Ju}$ & $\mathrm{Au}$ & Se & Oc \\
\hline \multicolumn{11}{|c|}{ (A) } \\
\hline Apiaceae & Daucus carota & & Wild carrot & & & & & & & \\
\hline Apocynaceae & Asclepias spp. & 3 & Milkweed & & & & & & & \\
\hline \multirow{14}{*}{ Asteraceae } & Achillea spp. & 2 & \multirow{14}{*}{$\begin{array}{c}\text { Common yarrow } \\
\text { Aster } \\
\text { Knapweed } \\
\text { Ox-eye daisy } \\
\text { Hawkweed } \\
\text { Fleabane } \\
\text { Elecampane } \\
\text { Wild chamomile } \\
\text { Coneflower, Black } \\
\text { eyed } \\
\text { Goldenrod } \\
\text { Spiny-leaved thristle } \\
\text { sow } \\
\text { Common tansy } \\
\text { Common dandelion } \\
\text { Meadow goatsbeard }\end{array}$} & & & & & & & \\
\hline & Aster spp. (2I) & $\begin{array}{l}2 \\
3\end{array}$ & & & & & & & & \\
\hline & Centaurea spp. $(2 \mathrm{D}, 2 \mathrm{E})$ & 3 & & & & & & & & \\
\hline & Leucanthemum vulgare & & & & & & & & & \\
\hline & Crepis capillaris & & & & & & & & & \\
\hline & Erigeron spp. & 3 & & & & & & & & \\
\hline & Inula helenium & & & & & & & & & \\
\hline & Matricaria chamomilla & & & & & & & & & \\
\hline & Rudbeckia spp. (2F) & 3 & & & & & & & & \\
\hline & Solidago spp. $(2 \mathrm{H})$ & 3 & & & & & & & & \\
\hline & Sonchus asper & & & & & & & & & \\
\hline & Tanacetum vulgare & & & & & & & & & \\
\hline & Taraxacum officinale & & & & & & & & & \\
\hline & Tragopogon pratensis & & & & & & & & & \\
\hline Brassicaceae & Erysimum cheiranthoides & & Wormseed mustard & & & & & & & \\
\hline & & & & & & & & & & \\
\hline \multirow[b]{2}{*}{ Caryophyllaceae } & Lychnis alba & & White campion & & & & & & & \\
\hline & $\begin{array}{l}\text { Silenecucubalus } \\
\text { Stellaria graminea }\end{array}$ & & $\begin{array}{l}\text { Blader campion } \\
\text { Grass-leaved starwort }\end{array}$ & & & & & & & \\
\hline Fabaceae & Trifolium spp. (2D) & \multirow[t]{2}{*}{2} & Clover & & & & & & & \\
\hline Lamiaceae & Monarda didyma & & Oswego tea & & & & & & & \\
\hline Onagraceae & Oenothera spp. & 2 & Primrose & & & & & & & \\
\hline \multirow{2}{*}{ Plantaginaceae } & Linaria vulgaris $(2 \mathrm{G})$ & \multirow{2}{*}{\multicolumn{2}{|c|}{$\begin{array}{c}\text { Butter and eggs } \\
\text { Common speedwell }\end{array}$}} & & & & & & & \\
\hline & Veronica officinalis & & & & & & & & & \\
\hline Polemoniaceae & Phlox pilosa & \multicolumn{2}{|r|}{ Downy phlox } & & & & & & & \\
\hline Ranunculaceae & Ranunculus spp. & \multicolumn{2}{|r|}{ Buttercup } & & & & & & & \\
\hline Rosaceae & Potentilla spp. & 5 & Cinquefoil & & & & & & & \\
\hline & & & (B) & & & & & & & \\
\hline Brassicaceae & $\begin{array}{c}\text { Sinapis alba } \\
\text { Brassica nigra }\end{array}$ & & $\begin{array}{l}\text { White mustard } \\
\text { Black mustard }\end{array}$ & & & & & & & \\
\hline Hydrophyllaceae & Phacelia tanacetifolia (2C) & & $\begin{array}{c}\text { Lacy phacelia Purple } \\
\text { Tansy }\end{array}$ & & & & & & & \\
\hline Polygonaceae & Fagopyrum esculentum & & Buckwheat & & & & & & & \\
\hline
\end{tabular}

Other considerations for managing plant biodiversity in cool-climate viticultural situations were: (1) the selected sown plants must have a rapid growth and provide adequate and sustained ecological services for several natural enemies present at different moments in the season. For example, nectariferous plants must bloom for a significant duration such that insects relying on nectar supply will be retained for a long period; (2) the flowering plants must be relatively inexpensive; (3) spontaneous flowering plants should remain established for several years; and (4) from an entomological point of view, the chosen plant species must not be a preferred host of a potential arthropod pest species. For 
example, the spotted wing drosophila (Drosophila suzukii-Drosophilidae), first identified in 2012 in Quebec vineyards [42], do not presently represent a threat to vineyards as grapes are not its preferred host. Enhancement of pollination services, a consideration often mentioned in scientific publications [43], is irrelevant in vineyards as entomophilous pollination is not required for grape production [2].

\section{Materials and Methods}

At the l'Orpailleur vineyard, two methods to mitigate winter damage to vines were implemented; with one method, plots where vines were hilled with soil in the fall were unhilled in spring (about $56 \%$ of surfaces at l'Orpailleur). This implied that the soil between vine rows was devoid of cover crops. However, spontaneous (i.e., native or non-native plants that emerged from seed bank or other means like rhizomes) plants can grow in surfaces adjacent to these plots. Annual plants (e.g., Phacelia sp.) were sown between vine rows. Over the years, we selected several plant species that were sown on a trialand-error basis on of surfaces of hilled/unhilled vine plots. One important consideration was that the routing system of these plants should not interfere with hilling/unhilling operations. In order to mitigate winter damage, with the second method, vines were covered with geotextiles in the fall and removed in spring (about $18 \%$ of surfaces). This allowed spontaneous vegetation to grow between vine rows or outside and areas adjacent to these plots. At the Bellevue site $\left(45^{\circ} 07^{\prime} 05^{\prime \prime} \mathrm{N}-72^{\circ} 49^{\prime} 16^{\prime \prime} \mathrm{W}\right)$ located ca. $3.2 \mathrm{~km}$ from the main vineyard/winery, plots with rustic vines (e.g., Frontenac blanc, Frontenac rouge, Musca oceola) were left unprotected for winter (about $26 \%$ of surfaces).

Meteorological data was gathered from Agrométéo Québec [44] as described in the Appendix A.

From 2014 to 2020, all plots were visited at least twice per week from 1 April (Woolly bud- B 03) to 1 October (Leaf fall- O 43) to: (1) determine the phenological stages of the vines; 2 ) identify and visually estimate the abundance of spontaneous flowering plants and their flowering period between vine rows of hilled/unhilled plots (at random on $3 \times 10 \mathrm{~m}$ strips), and non-hilled plots (at random on $5 \times 10 \mathrm{~m}$ strips) outside the vineyard and immediately adjacent surfaces; and (3) determine the abundance of selected arthropod species on cover crops between rows and on spontaneous plants growing in areas adjacent to cultivated plots. From April to harvest, the arthropods and their damage were visually monitored weekly on at least 100 vine plants per plot by one of us (J. Lasnier). Based on our experience, two species needed to be specifically monitored with the following methods.

At the woolly bud stage (B 03) (i.e., 25-day degrees $>10^{\circ} \mathrm{C}$ ), 3 pheromone traps were positioned in a 6 ha Seyval block (hilled/unhilled plot) to monitor adult male grape berry moths (Paralobesia viteana- Tortricidae). The traps (Multipher III, Trécé Inc., Salinas, CA, USA) were visited twice per week to determine the capture of male moths. The pheromone dispensers were changed every third week. Male moths were caught from the green shoot stage (D 06) until leaf fall (O 43), which coincided with the first freeze in the fall. For example, first freeze occurred at 1400 day-degrees $\left(>10^{\circ} \mathrm{C}\right)$ on 11 October $2018 ; 1189$ day-degrees $\left(>10^{\circ} \mathrm{C}\right)$ on 31 October 2019 , and 1297 day-degrees $\left(>10^{\circ} \mathrm{C}\right)$ on 8 October 2020. In the 6 ha plots where the traps were positioned, estimation of larval damage was carried out by random examination of 100 fruit clusters at the stage when berries were ripe (N 38) in 2018, 2019, and 2020.

In 2018, 2019, and 2020, the abundance of immatures and adults of the predator Anystis baccarum (Anystidae) (Figure 3A) was estimated twice per week by tapping 100 vine shoots, flower buds or fruit clusters over a $2 \mathrm{~L}$ plastic container. Specimens that fell into the container were tallied as Anystis baccarum immatures and adults on 100 shoots, flower buds or fruit clusters. 

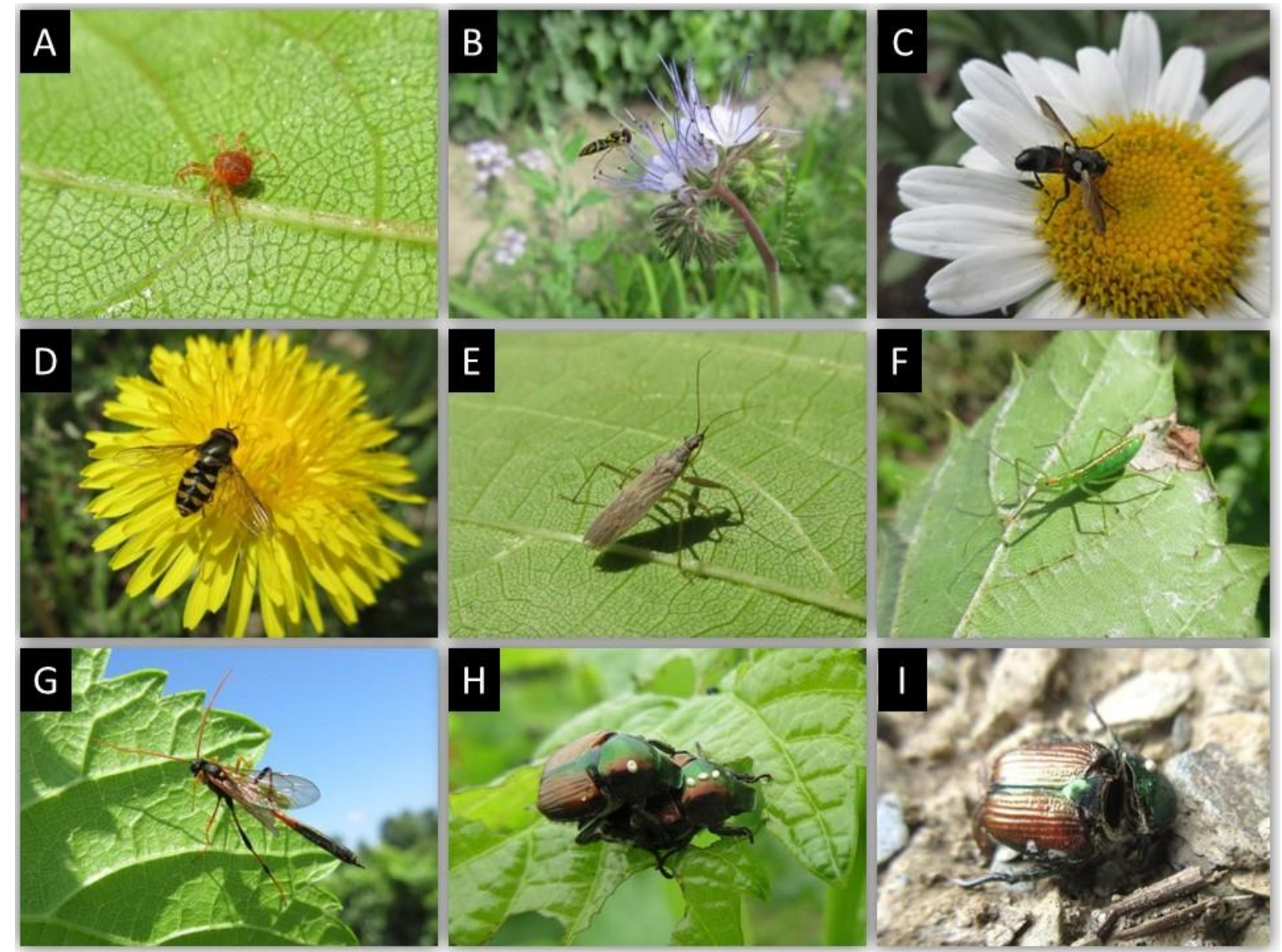

Figure 3. (A) Anystis baccarum (Anystidae) adult on vine leaf; (B) Allograpta obliqua (Syrphidae) adult feeding on a Phacelia flower; (C) Cylindromyia binota (Tachinidae) adult on a Leucanthemum vulgare flower; (D) Megasyrphus sp. (Syrphidae) adult feeding on a Taraxacum officinale (common dandelion) flower; (E) Nabis americoferus (Nabidae) adult under a grape leaf; (F) Zelus luridus (Reduviidae) nymph; (G) Therion fuscipennis (Ichneumonidae) adult; (H) Istocheta aldrichi (Tachinidae) eggs on pronotum of Popilllia japonica (Scarabaeidae) adult; (I) After devouring internal tissues of Popillia japonica (Scarabaeidae) adult, Istocheta aldrichi (Tachinidae) overwinters as pupa in the dead carcass of its host.

\section{Results and Discussion}

The most common species of spontaneous flowering plants belonged to 29 genera (12 families) (Table 2A). In vineyards that were hilled/unhilled, four species of annual plants belonging to three families were sown (Table 2B), and spontaneous flowers strips established immediately adjacent to the vineyards were left unmowed or were mowed in late fall.

A first mowing of spontaneous plants established between vine rows was conducted two weeks after the first peak captures of adult male grape berry moths (Paralobesia viteanaTortricidae) with pheromone traps, ca. 450 day-degrees $\left(>10^{\circ} \mathrm{C}\right)$ (Figure 4$)$. This allowed generalist predators and adults of braconid, tachinid, and ichneumonid parasites to feed on floral resources. Several parasitoids of lepidopteran larvae, such as Therion fuscipennis (Ichneumonidae) (Figure 3G), were found on flower strips. A second mowing of plants between vine rows was conducted at the end of August (after the second peak of captures of adult male grape berry moths), thus providing time for parasitism to effectively occur. Egg parasitism of grape berry moth by Trichogramma spp., as reported in Pennsylvania by Nagarkatti et al. [45], was also found. At the stage when berries were ripe (N 38), there were respectively 2, 0, and 1 larva/100 clusters examined in 2018, 2019, and 2020. These low population levels did not warrant insecticidal treatments. 


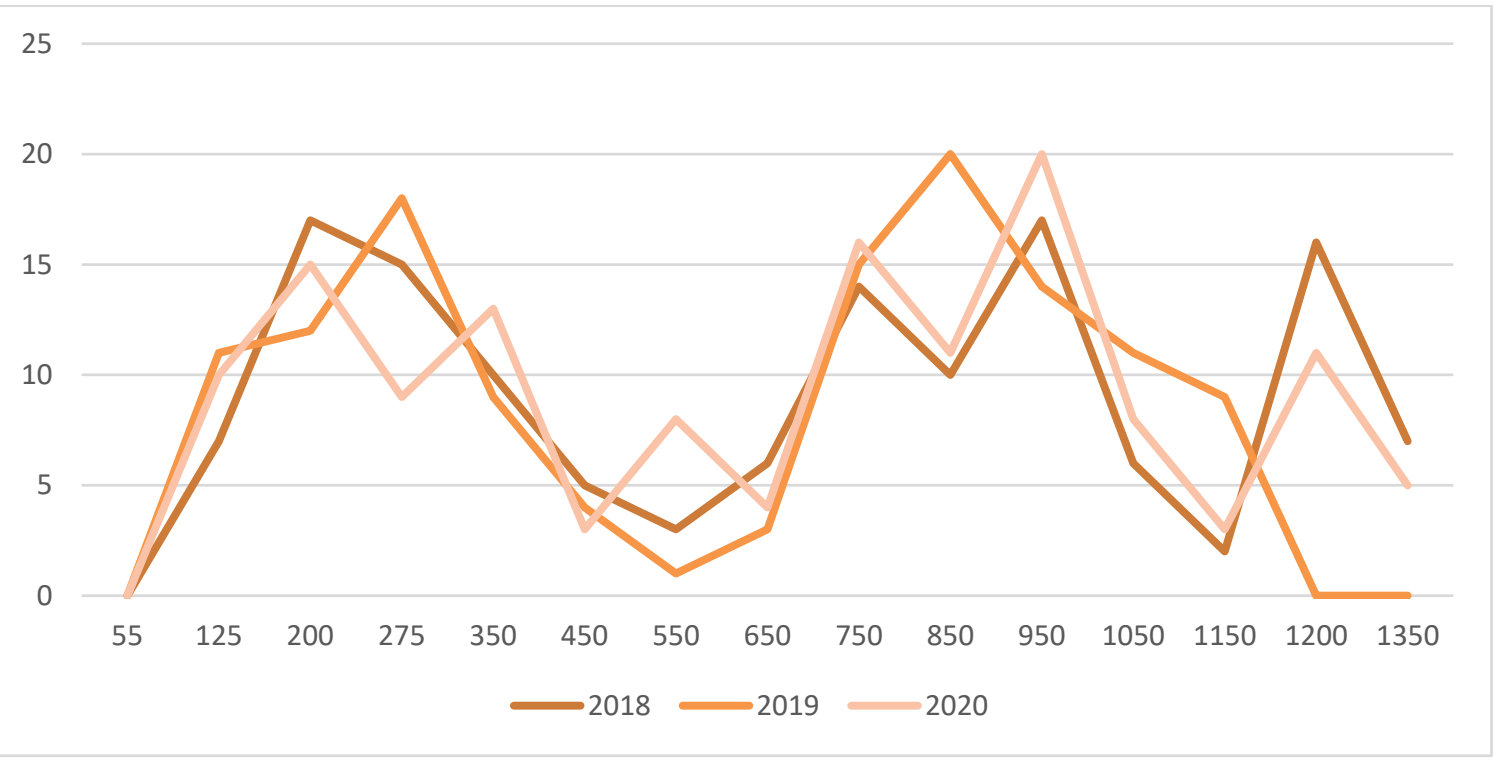

Figure 4. Total captures of adult male grape berry moths (Paralobesia viteana) by 3 pheromone traps positioned in a 6 ha Seyval plot at l'Orpailleur vineyard in 2018, 2019 and 2020. Horizontal axis are day degrees $\left(>10{ }^{\circ} \mathrm{C}\right)$ starting at the green-shoot stage (D 06).

Amongst the 60 cicadellid species found in Quebec vineyards [26,29], the most common were Empoasca fabae, Erythroneura comes, Erythroneura tricincta, Erythroneura ziczac and Erythroneura vitis. The predatory mite Anystis baccarum (Anystidae) was an efficient predator of nymphs and adult leafhopper. It has two generations per season in Quebec. Nymphs were found at the beginning of June (Figure 5). The first generation ended by mid-July. The peak of the second generation occurred at the end of August. To foster predation of cicadellids by immatures and adults of the two generations of A. baccarum, flower strips were maintained between vine rows and areas adjacent to cultivated vines.

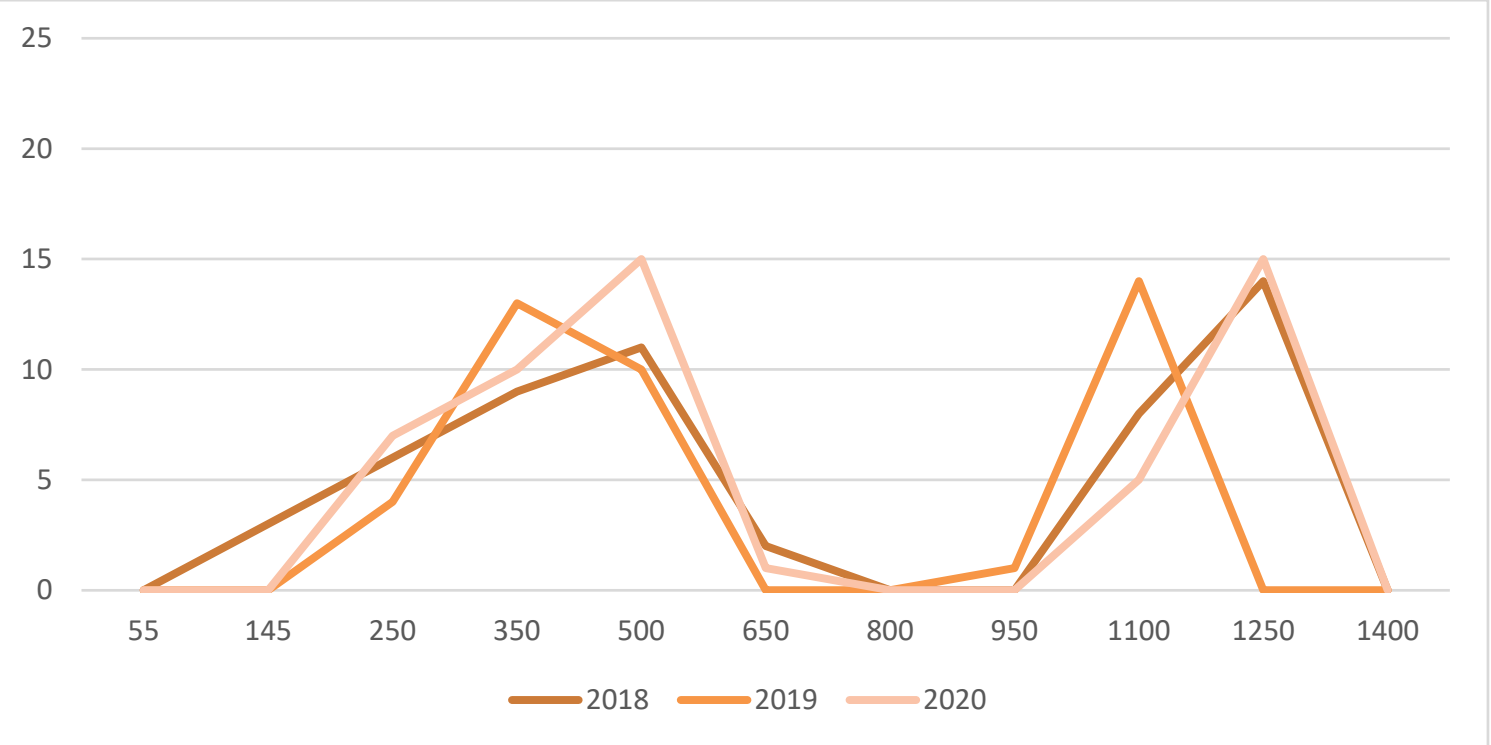

Figure 5. Abundance of Anystis baccarum immatures and adults on 100 fruit buds/clusters in 2018, 2019 , and 2020. Horizontal axis are day degrees $\left(>10^{\circ} \mathrm{C}\right)$ starting at the green-shoot stage (D 06).

The flower strips also conserved other predators and parasites (Table 3). For example, the chrysopids Chrysopa carnea and Hemerobius humilinus; the coccinellids Coccinella septem- 
punctata, Coleomegilla maculata, Harmonia axyridis and Hippodamia spp.; the nabid Nabis spp.; and the reduviid Zelus spp. (Figure 3F) were often observed predating on several stages of leafhoppers. We also observed egg parasites of leafhoppers, as reported in New York State by Williams and Martinson [46] and English-Loeb et al. [47].

Table 3. Most common beneficials found on vines and on spontaneous flowering species strips established between vines and areas adjacent to the vineyard. (Figure 2C,D) and adjacent to the vineyard (Figure 2E-I) at the l'Orpailleur vineyard, Dunham, QC. Prey: 1 = several species; 2 = phytophagous mites; $3=$ leafhoppers; 4 = lepidopteran immatures; $5=$ aphids; $6=$ mealybugs; 7 = Pentatomidae, Miridae; $8=$ Popillia japonica $; \mathrm{x}=$ minimally abundant and occasional; $\mathrm{xx}=$ moderately abundant and common; $x x x=$ abundant and common; $x x x x=$ very abundant and common.

\begin{tabular}{|c|c|c|c|c|}
\hline Order & Family & Latin Name (Figure No.) & Prey & Abundance \\
\hline \multirow{4}{*}{ Araneae } & \multirow{3}{*}{ Araneidae } & Araneus diadematus & 1 & $x x$ \\
\hline & & Araniella displicata & 1 & $x x$ \\
\hline & & Argiope aurantia & 1 & $x$ \\
\hline & Thomisidae & Xysticus spp. & 1 & $\mathrm{x}$ \\
\hline \multirow{5}{*}{ Coleoptera } & \multirow{5}{*}{ Coccinellidae } & Anatis spp. & 1 & $\mathrm{x}$ \\
\hline & & Coccinella septempunctata & 1 & $x x$ \\
\hline & & Harmonia axyridis & 1 & $x x x$ \\
\hline & & Hippodamia convergens & 1 & $x x$ \\
\hline & & Coleomegilla maculata & 1 & $x x x$ \\
\hline \multirow{8}{*}{ Diptera } & \multirow{5}{*}{ Syrphidae } & Allograpta obliqua (3B) & 1 & $x x$ \\
\hline & & Megasyrphus spp. (3D) & 1 & $x x$ \\
\hline & & Ocyptamus fascipennis & 6 & $x x$ \\
\hline & & Syrphus rectus & 1 & $x x$ \\
\hline & & Toxomerus spp. & 1 & $x x$ \\
\hline & \multirow{3}{*}{ Tachinidae } & Cylindromyia binota (3C) & 7 & $x x$ \\
\hline & & Istocheta aldrichi (3H-3I) & 8 & $x x x x$ \\
\hline & & Jurinia pompalis & 4 & $x x$ \\
\hline \multirow{3}{*}{ Hemiptera } & Nabidae & Nabis americoferus (3E) & 1 & $x x$ \\
\hline & & Nabis roseipennis & 1 & $x x$ \\
\hline & Reduviidae & Zelus luridus (3F) & 1 & $x \mathrm{x}$ \\
\hline \multirow{2}{*}{ Mesostigmata } & \multirow{2}{*}{ Phytoseiidae } & Amblydromella spp. & 2 & $x$ \\
\hline & & Neoseiulus fallacis & 2 & $x$ \\
\hline \multirow{2}{*}{ Trombidiformes } & Anystidae & Anystis baccarum (3A) & 2.3 & $x \times x x$ \\
\hline & Trombidiidae & Allothrombium lerouxii & $2,3,4$ & $x$ \\
\hline \multirow{5}{*}{ Hymenoptera } & Braconidae & Aleiodes spp. & 4 & $\mathrm{x}$ \\
\hline & Ichneumonidae & Therion spp. (3G) & 4 & $x x$ \\
\hline & & Ichneumon spp. & 4 & $x x$ \\
\hline & Mymaridae & Anagrus spp. & 3 & $x$ \\
\hline & Trichogrammatidae & Trichogramma spp. & 4 & $x$ \\
\hline \multirow{3}{*}{ Neuroptera } & Chrysopidae & Chrysoperla carnea & 1 & $x x$ \\
\hline & & Chrysopa oculata & 1 & $x x$ \\
\hline & Hemerobiidae & Hemerobius spp. & 1 & $x x$ \\
\hline
\end{tabular}


Some phytophagous mirids and pentatomids were parasitized by the tachinid Cylindromya binota (Figure 3C), a species frequently found in flower strips. This species, reported by Normandin [48], could also be important for the biocontrol of the brown marmorated stink bug (Halyomorpha halys- Pentatomidae).

A highly polyphagous insect native to northern China, Japan, and Far East of Russia, the Japanese beetle (Popillia japonica- Scarabaeidae) was first discovered in North America in Riverton, New Jersey, in 1916 [49-51]. As of 1983, it was present on ornamental roses grown in Bedford, Qc, a locality near the Quebec/Vermont border [52]). Reported as a pest of New England vineyards [53], it has been present in vineyards of southern Quebec since 2010, its populations increasing ever since [54]. From 1920-1933, the United States Department of Agriculture (USDA) imported and released 49 species of natural enemies in Northeastern USA, including Istocheta aldrichi, a tachinid that parasitizes newly emerged adults [50]. Reported in Ontario by O'Hara [55], I. aldrichi was observed in 2014 associated with Japanese beetle adults in vineyards of Southern Quebec [54]. Following oviposition of their eggs on the pronotum of Japanese beetle adults (Figure 3H), I. aldrichi complete their larval development and pupate in their host, which mummifies before winter (Figure 3I). The following year, I. aldrichi adults emerge around two weeks before the appearance of Japanese beetle adults [54]. Before the availability of their host, I. aldrichi adults feed on nectar of flowering plants in the vineyards. In plots where a high proportion of Japanese beetle adults had of I. aldrichi eggs on their pronotum, natural control was effective and Japanese beetle populations and their damage were maintained at tolerable levels in 2018, 2019, and 2020 such that insecticidal treatment was not necessary.

Other services provided by managing biodiversity in vineyards. As argued by Garcia et al. [8], viticulturists generally pursue several objectives when deliberately increasing plant biodiversity. For example, in semi-arid vineyards of British Columbia, Canada, Vukicevich et al. $[56,57]$ demonstrated that the management of cover plants can change root fungal communities and plant-soil feedback.

Currently, wine consumers are increasingly demanding wine produced with environmentally sustainable practices, as exemplified by Tompkins et al. [39] for New Zealand and de Coussergues [58] in Quebec. Enhancing plant diversity in vineyards addresses this demand.

Increasing diversity of plants can also be a way to enhance the aesthetic experience of agrotourists visiting wineries (Figure 2B). Some viticulturists of Southern Quebec further increased the aesthetic experience by organizing symposia of sculptures amongst ornamental plants growing adjacent to their vineyards (Figure 2A).

Three phases of entomological research culminated in managing biodiversity

A series of research projects that occurred over three phases allowed for the development of sustainable protection programs for Quebec vineyards. In a first phase beginning in 1997, assessment of the biodiversity of arthropods in insecticide-free plots as part of two commercial vineyards was carried out to establish baselines. Key arthropod pests and the risk they incurred was identified (see Table 2 in [59]; Table 1 in [21]). In a second phase beginning in 2004, arthropod problems were researched on an ad hoc basis, and we applied the main principles involved in Integrated Pest Management relevant to viticulture [60]: know your pests, favour natural enemies, monitor pests, and apply pesticides as a last resort. In this phase, research on the biodiversity of leafhoppers was critical to address a potential problem caused by phytoplasmas. In a third phase beginning in 2014, management of plant diversity in the vineyard and its adjacent surroundings has been adopted as a practice to conserve natural enemies with the aim to provide a broad-reaching control measure such that commercially acceptable yields of grapes would be achieved with low quantities of insecticides and acaricides per ha. In 1997, participating vineyards applied approximately five insecticide acaricide sprays per season. Since 2010, $<1.5$ insecticide sprays have been applied per season at l'Orpailleur. Since 2015, only one insecticide spray was applied before bloom (I 23), and none were applied from the time the fruit set (J 27) until harvest (N 38). This constitutes our entomological benchmark by 
which we appraise our overall success in terms of protection program, including the effect of managing plant biodiversity.

\section{Looking forward}

The current protection programs practiced in Quebec vineyards will likely be challenged by a number of factors. First, challenges incurred by invasive arthropods will need to be addressed as they come. The spotted wing drosophila (Drosophila suzukiiDrosophilidae) was found in 2012 in Quebec vineyards [42] and, at present, it is not a concern for viticulturist as grape is a non-preferred host. The brown marmorated stink bug (Halyomorpha halys- Pentatomidae) [61] has been reported in the Montreal area from 2008 to 2018 [62,63] but, as of 2020, it has not been reported as a pest of vineyards. The grape rootworm (Fidia viticida-Chrysomelidae), an insect native to North America hitherto restricted to Ontario in Canada, was found in 2016 associated with Parthenocissus quinquefolia and Vitis riparia in Laval, QC [64]. Absent before 2018, the grape plume moth (Geina periscelidactylus-Pterophoridae) was recently found in Quebec vineyards. Although these arthropods are a minor addition to the biodiversity of arthropods, their advent is a cause of concern because they have the potential to upset existing programs.

Some pests present in Southern Ontario, such as the blotch leafminer (Antispila viticordifoliella-Heliozelidae), the grape mealybug (Pseudococcus maritimus-Pseudococcidae), the European fruit lecanium scale (Parthenolecanium corni-Coccidae), the grape cane girdler (Ampeloglypter ampelopsis-Curculionidae), and the grape cane gallmaker (Ampeloglypter sesostris-Curculionidae), may expand their current geographical distribution under climate change scenarios. The spotted lanternfly (Lycorma delicatula-Fulgoridae) has been found for the first time in 2014 in Pennsylvania and, as of 2019, was present in several New England States [65]. It is polyphagous ( $>65$ host plants), and Vitis vinifera is one of its preferred hosts. As of 2021, it was absent from Canada, and has been added to the list of regulated species by the Canadian Food Inspection Agency [66]. If present, this species is likely to cause some concerns to viticulturists and impact protection programs.

Second, grapevine diseases vectored by insects are increasingly causing concern to viticulturists. In 2006, Bois noir was first detected in Canada by Rott et al. [67] and was quickly eradicated. This prompted research on phytoplasmas associated with grapevines in Canada as well as their insect vectors, notably cicadellids [29,47,68]. Amongst the 37 leafhopper species that were phytoplasma DNA-positive, 11 are known vectors, the strongest potential vector being Macrosteles quadrilineatus (Cicadellidae). As of 2020, Flavescence dorée and Bois noir, two quarantine phytoplasmas associated with cultivated grapewines were absent from Canada.

From 2006 to 2008, a study about leafroll-associated virus and their vectors was conducted in the Finger Lakes region of New York State [69]. Grape mealybug (Pseudococcus maritimus-Pseudococcidae), European fruit lecanium (Parthenolecanium corni-Coccidae), and cottony maple scale (Pulvinaria acericola-Coccidae) were identified as vector species. In the 2010s, viral diseases associated with cultivated grapevines were increasingly reported. In surveys conducted in vineyards of British Columbia (Canada) in 2014 and 2015, Poojari et al. [70] found several viruses, the most prevalent being GLRaV-3 (16.7\% of composite samples). Present at low levels, Pseudococcus maritimus (Pseudococcidae) and Parthenolecanium corni (Coccidae) were identified by barcoding. In 2018-2019 in Quebec vineyards, three viruses (i.e., grapevine rupestris stem pitting-associated virus, grapevine leafroll-associated virus (GLRaV) 3 and 2, and hop stunt viroid (HSVd)) largely dominated the virome of grapevines [71]. Currently, mealybugs and soft scales are at very low levels in Quebec vineyards and their management with plant diversity have yet to be researched to develop efficient and sustainable management methods for phytoplasmas and virus vectors. Biovigilance of established and newly established arthropods species is in order.

Third, the advent of climate change scenarios will directly impact the development all arthropods as they are poikilotherms, as well as cultivated and non-cultivated plants. Climate change is likely to shift the types of vines cultivated worldwide [72-76]. Based on a probabilistic model, Roy et al. [77] evoked several scenarios involving temperature increase 
such that Vitis vinifera will survive winters by 2040-2050 and new regions of Quebec will be amenable to viticulture. However, they point out uncertainties related to abundant rainfall and cloud cover that could negatively impact vine growth and grape production. All the plants in vineyards and areas adjacent to them will also be impacted. It is believed that being at the edge of cool-climate, Quebec viticulture will benefit from climate change scenarios. These scenarios overlook uncertainties related to extreme temperature variations in summer (i.e., variations in the duration of frost-free growing season) and winter (i.e., variation in below-freezing temperatures and snow cover in winter). Climate change will impact plants and arthropods unequally, creating more uncertainty for the whole viticultural industry. Consequently, an update of our current protection program, including management of arthropods with plant biodiversity, will have to be performed to cope with the prevailing situation.

Author Contributions: Conceptualization, C.V., J.L., C.-H.d.C., A.B.; writing-original draft preparation, C.V.; writing-review and editing, C.V., J.L., C.-H.d.C., A.B.; photographs, J.L.; project administration, C.V.; funding acquisition, C.V. All authors have read and agreed to the published version of the manuscript.

Funding: Agriculture and Agri-Food Canada.

Institutional Review Board Statement: Not applicable.

Informed Consent Statement: Not applicable.

Data Availability Statement: Not applicable.

Acknowledgments: We thank Jérémie Côté for technical input in preparing the manuscript, and Noubar J. Bostanian, Josée St-Pierre and Alain Bazinet for commenting on the manuscript. We thank the professional input of our colleagues' taxonomists from Agriculture and Agri-Food Canada, Ottawa, notably Henri Goulet (Carabidae), Patrice Bouchard (Curculionidae), Andy Hamilton (Cicadellidae), Laurent Lesage (Chrysomelidae) and Jean-François Landry (Lepidoptera), as well as Chris Buddle (Aranae) from McGill University. We also thank the technical input of Benoit Rancourt, Martin Trudeau, Pierre Lemoyne and Gaétan Racette. We thank Agriculture and Agri-Food Canada for financial support since 1997.

Conflicts of Interest: The authors declare no conflict of interest.

\section{Appendix A}

As briefly referred to in Materials and Methods, meteorological data was gathered from Agrométéo Québec [44] with the following steps: Step 1- Click on section « Sommaire et prévision»; Step 2- Click on «Quotidien ?»; Step 3- Select a stating and ending date by clicking «Choisir une date» and «Fin du sommaire»; Step 4- Chose a base temperature by clicking «Choix de la $\mathrm{T}^{\mathrm{O}}$ de base». We chose $10^{\circ} \mathrm{C}$; Step 5- Chose a station. We chose «Dunham » and saved it; Step 6- Generate a table according to the previously defined parameters by clicking «Obtenir sommaire».

\section{References}

1. Arroyo-García, R.; Ruiz-García, L.; Bolling, L.; Ocete, R.; López, M.A.; Arnold, C.; Ergul, A.; Söylemezoğlu, G.; Uzun, H.I.; Cabello, F.; et al. Multiple origins of cultivated grapevine (Vitis vinifera L. ssp. sativa) based on chloroplast DNA polymorphisms. Mol. Ecol. 2006, 15, 3707-3714. [CrossRef] [PubMed]

2. $\quad$ Keller, M. The Science of Grapevines, 3rd ed.; Academic Press: Cambridge, MA, USA, 2020; p. 543.

3. Daane, K.M.; Vincent, C.; Isaacs, R.; Ioriatti, C. Entomological Opportunities and Challenges of Sustainable Viticulture in a Global Market. Annu. Rev. Entomol. 2018, 63, 193-214. [CrossRef] [PubMed]

4. OIV. Statistical Report on World Vitiviniculture 2019. Available online: http://www.oiv.int/public/medias/6782/oiv-2019 -statistical-report-on-world-vitiviniculture.pdf (accessed on 7 December 2020).

5. Altieri, M.A.; Ponti, L.; Nicholls, C.I. Manipulating vineyard biodiversity for improved insect pest management: Case studies from northern California. Int. J. Biodivers. Sci. Ecosyst. Serv. Manag. 2005, 1, 191-203. [CrossRef]

6. Lebon, E.; Garcia de Cortazar-Atauri, I. Dans un contexte de changement climatique, quels sont les impacts de la sécheresse sur la vigne et sur le devenir des vignobles ? L'exemple du Languedoc. Innov. Agron. 2014, 38, 1-12. 
7. Sirnik, I.; Quénol, H.; Jimenez-Bello, M.A.; Manzano-Juarez, J.; Le Roux, R. Viticulture under climate change impact: Future climate and irrigation modeling. E3S Web Conf. EDP Sci. 2018, 50, 01041. [CrossRef]

8. Ayphassorho, H.; Bertrand, N.; Mitteault, F.; Pujos, C.; Rollin, D.; Sallenave, M. Changement climatique, eau, agriculture Quelles trajectoires d'ici 2050. In Rapport CGEDD; Ministère de la Transition Ecologique, Ministère de L'Agriculture et de l'Alimentation: Paris, France, 2020; p. 333, n 012819-01, CGAAER nº 19056.

9. Gerling, C. Environmentally Sustainable Viticulture: Practices and Practicality; CRC Press: Boca Raton, FL, USA, $2015 ;$ p. 414.

10. Santini, C.; Cavicchi, A.; Casini, L. Sustainability in the wine industry: Key questions and research trend. Agric. Econ. 2013, 1,9. [CrossRef]

11. Altieri, M.A. The ecological role of biodiversity in agroecosystems. Agric. Ecosyst. Environ. 1999, 74, 19-31. [CrossRef]

12. Altieri, M.A. Agroecology: Key Concepts, Principles and Practices; Third World Network: Penang, Malaysia; Sociedad Cientifica Latinoamericana de Agroecologia: Berkeley, CA, USA, 2015; p. 55.

13. Ratnadass, A.; Fernandes, P.; Avelino, J.; Habib, R. Plant species diversity for sustainable management of crop pests and diseases in agroecosystems: A review. Agron. Sustain. Dev. 2012, 32, 273-303. [CrossRef]

14. Altieri, M.A.; Nicholls, C.I.; Montalba, R. Technological Approaches to Sustainable Agriculture at a Crossroads: An Agroecological Perspective. Sustainability 2017, 9, 349. [CrossRef]

15. Garcia, L.; Celette, F.; Gary, C.; Ripoche, A.; Valdés-Gómez, H.; Metay, A. Management of service crops for the provision of ecosystem services in vineyards: A review. Agric. Ecosyst. Environ. 2018, 251, 158-170. [CrossRef]

16. Burgio, G.; Marchesini, E.; Reggiani, N.; Montepaone, G.; Schiatti, P.; Sommaggio, D. Habitat management of organic vineyard in Northern Italy: The role of cover plants management on arthropod functional biodiversity. Bull. Entomol. Res. 2016, 106, 759-768. [CrossRef]

17. Zanettin, G.; Bullo, A.; Pozzebon, A.; Burgio, G.; Duso, C. Influence of Vineyard Inter-Row Groundcover Vegetation Management on Arthropod Assemblages in the Vineyards of North-Eastern Italy. Insects 2021, 12, 349. [CrossRef] [PubMed]

18. Vogelweith, F; Thiéry, D. Cover crop differentially affects arthropods, but not diseases, occurring on grape leaves in vineyards. Aust. J. Grape Wine Res. 2017, 23, 426-431. [CrossRef]

19. Möth, S.; Walzer, A.; Redl, M.; Petrović, B.; Hoffmann, C.; Winter, S. Unexpected Effects of Local Management and Landscape Composition on Predatory Mites and Their Food Resources in Vineyards. Insects 2021, 12, 180. [CrossRef]

20. Fiera, C.; Ulrich, W.; Popescu, D.; Bunea, C.-I.; Manu, M.; Nae, I.; Stan, M.; Markó, B.; Urák, I.; Giurginca, A.; et al. Effects of vineyard inter-row management on the diversity and abundance of plants and surface-dwelling invertebrates in Central Romania. J. Insect. Conserv. 2020, 24, 175-185. [CrossRef] [PubMed]

21. Vincent, C.; Lasnier, J. Sustainable Arthropod Management in Quebec Vineyards. Agriculture 2020, 10, 91. [CrossRef]

22. Vincent, C.; Lemoyne, P.; Gaul, S.; MacKenzie, K. Factors limiting the northern distribution of the Blueberry maggot in Eastern Canada. Eur. J. Entomol. 2016, 113, 143-149. [CrossRef]

23. Bussières McNicoll, F.; Une Année Fructueuse Pour les Vignerons du Québec. Radio-Canada. 2020. Available online: https: / /ici.radio-canada.ca/nouvelle/1740231/recolte-vin-vignoble-vendange-quebec-monteregie?fromApp=appInfolos\& partageApp=appInfoiOS\&accesVia=partage (accessed on 4 November 2020).

24. Bloesch, B.; Viret, O. Stades phénologiques repères de la vigne. Rev. Suisse Vitic. Arboric. Hortic. 2008, 40, 6-10.

25. Conseil des Vins du Québec 2019. Available online: https://vinsduquebec.com/a-propos/ (accessed on 7 December 2020).

26. Bostanian, N.J.; Vincent, C.; Goulet, H.; LeSage, L.; Lasnier, J.; Bellemare, J.; Mauffette, Y. The Arthropod Fauna of Quebec Vineyards, with particular reference to phytophagous species. J. Econ. Entomol. 2003, 96, 1221-1229. [CrossRef] [PubMed]

27. Bostanian, N.J.; Vincent, C.; Isaacs, R. Arthropod Management in Vineyards: Pests, Approaches, and Future Directions; Springer: Dordrecht, The Netherlands, 2012; p. 505.

28. Vincent, C.; Bostanian, N.J.; Lasnier, J. Biodiversity and management of arthropods in cool-climate vineyards. In Proceedings of the of the 2nd International Conference on Northern Viticulture, Saint-Hyacinthe, QC, Canada, 9-11 November 2009; pp. 189-199.

29. Saguez, J.; Olivier, C.; Hamilton, A.; Lowery, T.; Stobbs, L.; Lasnier, J.; Galka, B.; Chen, X.; Mauffette, Y.; Vincent, C. Diversity and abundance of leafhoppers (Hemiptera: Cicadellidae) in Canadian vineyards. J. Insect Sci. 2014, 14, 73. [CrossRef]

30. Lucas, E.; Vincent, C.; Labrie, G.; Chouinard, G.; Fournier, F.; Pelletier, F.; Bostanian, N.J.; Coderre, D.; Mignault, M.P.; Lafontaine, P. The multicolored Asian ladybeetle Harmonia axyridis (Coleoptera: Coccinellidae) in Quebec agroecosystems ten years after its arrival. Eur. J. Entomol. 2007, 104, 737-743. [CrossRef]

31. Kreiter, S. Pest Management in Organic Grape Production. In Handbook of Pest Management in Organic Farming; Vacante, V., Kreiter, S., Eds.; CABI: Wallingford, UK, 2018; pp. 173-217.

32. Fleury, D.; Paré, J.; Vincent, C.; Mauffette, Y. Feeding impact of Lygus lineolaris (Heteroptera: Miridae) on Vitis vinifera: A behavioural and histological study. Can. J. Bot. 2006, 84, 493-500. [CrossRef]

33. Fleury, D.; Mauffette, Y.; Méthot, S.; Vincent, C. Population activity of Lygus lineolaris (Heteroptera: Miridae) adults at the periphery and inside a commercial vineyard. Eur. J. Entomol. 2010, 107, 527-534. [CrossRef]

34. Bostanian, N.J.; Goulet, H.; O’Hara, J.; Masner, L.; Racette, G. Towards Insecticide Free Apple Orchards: Flowering Plants to Attract Beneficial Arthropods. Biocontrol. Sci. Technol. 2004, 14, 25-37. [CrossRef]

35. Fernández-Triana, J.; Goulet, H.; Bostanian, N.J.; Boudreault, C. Diversity of Microgastrinae (Hymenoptera: Braconidae) in apple orchards of southern Quebec, Canada. Biocontrol. Sci. Technol. 2009, 19, 237-248. [CrossRef]

36. Vincent, C.; Lowery, T.; Parent, J.-P. The Entomology of Vineyards in Canada. Can. Entomol. 2018, 150, 697-715. [CrossRef] 
37. Brouillet, L.; Coursol, F.; Meades, S.J.; Favreau, M.; Anions, M.; Bélisle, P.; Desmet, P. Vitis, in VASCAN, the Database of Vascular Plants of Canada. 2010. Available online: http:/ / data.canadensys.net/vascan/name/Vitis (accessed on 7 December 2020).

38. Lasnier, J.; McFadden-Smith, W.; Moreau, D.; Bouchard, P.; Vincent, C. Guide to the Key Arthropods of Vineyards of Eastern Canada; Technical Bulletin, Agriculture and Agri-Food Canada: Ottawa, ON, Canada, 2019; p. 114.

39. Tompkins, J.-M.; Wratten, S.D.; Simpson, M. Enhancing Ecosystem Services in Australasian Vineyards for Sustainability and Profit. In Arthropod Management in Vineyards: Pests, Approaches, and Future Directions; Bostanian, N.J., Vincent, C., Isaacs, R., Eds.; Springer: Dordrecht, The Netherlands, 2012; pp. 139-157.

40. Miles, A.; Wilson, H.; Altieri, M.; Nicholls, C. Habitat Diversity at the Field and Landscape Level: Conservation Biological Control Research in California Viticulture. In Arthropod Management in Vineyards: Pests, Approaches, and Future Directions; Bostanian, N.J., Vincent, C., Isaacs, R., Eds.; Springer: Dordrecht, The Netherlands, 2012; pp. 159-188.

41. Wilson, K.; Daane, K.M. Review of Ecologically-Based Pest Management in California Vineyards. Insects 2017, 8, 108. [CrossRef]

42. Saguez, J.; Lasnier, J.; Vincent, C. First record of Drosophila suzukii in Quebec vineyards. J. Int. Sci. Vigne Vin 2013, 47, 69-72. [CrossRef]

43. Albrecht, M.; Kleijn, D.; Williams, N.M.; Tschumi, M.; Blaauw, B.R.; Bommarco, R. The effectiveness of flower strips and hedgerows on pest control, pollination services and crop yield: A quantitative synthesis. Ecol. Lett. 2020, 23, 1488-1498. [CrossRef]

44. Agrométéo Québec. Available online: www.agrometeo.org/indices/category/generalLocation:Dunham,Qc (accessed on 10 June 2021).

45. Nagarkatti, S.; Muza, A.J.; Saunders, M.C.; Tobin, P.C. Role of the egg parasitoid Trichogramma minutum in biological control of the grape berry moth. Endopiza viteana. BioControl 2002, 47, 373-385. [CrossRef]

46. Williams, L.; Martinson, T.E. Colonization of New York vineyards by Anagrus spp. (Hymenoptera: Mymaridae): Overwintering biology, within-vineyard distribution of wasps, and parasitism of grape leafhopper, Erythroneura spp. (Homoptera: Cicadellidae), eggs. Biol. Control. 2000, 18, 136-146. [CrossRef]

47. English-Loeb, G.; Rhainds, M.; Martinson, T.; Ugine, T. Influence of flowering cover crops on Anagrus parasitoids (Hymenoptera: Mymaridae) and Erythroneura leafhoppers (Homoptera: Cicadellidae) in New York. Agric. Forest. Entomol. $2003,5,173-181$. [CrossRef]

48. Normandin, E. Les Insectes du Québec et Autres Arthropodes Terrestres; Les Presses de l'Université de Montréal: Montréal, QC, Canada, 2020; p. 620.

49. Britton, W.E.; Johnson, J.P. The Japanese beetle in Connecticut. Conn. Agric. Exp. Stn. Bull. 1938, 411, 455-486.

50. Cappaert, D.L.; Smitley, D.R. Parasitoids and Pathogens of Japanese Beetle (Coleoptera: Scarabaeidae) in Southern Michigan. Environ. Entomol. 2002, 31, 573-580. [CrossRef]

51. Potter, D.A.; Held, D.W. Biology and management of the Japanese beetle. Annu. Rev. Entomol. 2002, 47, 175-205. [CrossRef]

52. Vincent, C.; Agriculture and Agri-Food Canada, Saint-Jean-sur-Richelieu, QC, Canada. Personal communication, 2020.

53. Pfeiffer, D.G. Japanese Beetle and Other Coleoptera Feeding on Grapevines in Eastern North America. In Arthropod Management in Vineyards: Pests, Approaches, and Future Directions; Bostanian, N.J., Vincent, C., Isaacs, R., Eds.; Springer: Dordrecht, The Netherlands, 2012; pp. 403-429.

54. Lasnier, J.; Co-Lab R\&D, Granby, QC, Canada. Personal communication, 2020.

55. O'Hara, J.E. New tachinid records for the United States and Canada. Tachinid Times 2014, 27, 34-40.

56. Vukicevich, E.; Lowery, D.T.; Úrbez-Torres, J.R.; Bowen, P.; Hart, M. Groundcover management changes grapevine root fungal communities and plant-soil feedback. Plant Soil 2018, 424, 419-433. [CrossRef]

57. Vukicevich, E.; Lowery, D.T.; Bennett, J.A.; Hart, M. Influence of Groundcover Vegetation, Soil Physicochemical Properties, and Irrigation Practices on Soil Fungi in Semi-arid Vineyards. Front. Ecol. Evol. 2019, 7, 118. [CrossRef]

58. De Coussergues, C.-H.; Vignoble de l'Orpailleur, Dunham, QC, Canada. Personal communication, 2020.

59. Vincent, C.; Lasnier, J. Les arthropodes des vignobles québécois. Phytoma 2016, 697, 45-48.

60. Vincent, C.; Isaacs, R.; Bostanian, N.J.; Lasnier, J. Principles of Arthropod Pest Management in Vineyards. In Arthropod Management in Vineyards: Pests, Approaches, and Future Directions; Bostanian, N.J., Vincent, C., Isaacs, R., Eds.; Springer: Dordrecht, The Netherlands, 2012; pp. 1-16.

61. Leskey, T.C.; Nielsen, A.L. Impact of the Invasive Brown Marmorated Stink Bug in North America and Europe: History, Biology, Ecology, and Management. Annu. Rev. Entomol. 2018, 63, 599-618. [CrossRef]

62. Fogain, R.; Graff, S. First record of the invasive pest, Halyomorpha halys (Hemiptera: Pentatomidae), in Ontario and Quebec. J. Entomol. Soc. Ont. 2011, 142, 45-48.

63. Chouinard, G.; Larose, M.; Légaré, J.-P.; Bourgeois, G.; Racette, G.; Barrette, M. Interceptions and captures of Halyomorpha halys (Hemiptera: Pentatomidae) in Quebec from 2008 to 2018. Phytoprotection 2018, 98, 46-50. [CrossRef]

64. Vincent, C.; Dumont, S.; de Tonnancour, P. The grape rootworm, Fidia viticida (Coleoptera: Chrysomelidae), newly recorded from Quebec. Phytoprotection 2017, 91, 17-19. [CrossRef]

65. Lee, D.-H.; Park, Y.-L.; Leskey, T.C. A review of biology and management of Lycorma delicatula (Hemiptera: Fulgoridae), an emerging global invasive species. J. Asia-Pacific Entomol. 2019, 22, 589-596. [CrossRef]

66. Canadian Food Inspection Agency. Spotted lanternfly (Lycorma delicatula). 2020. Available online: https://www.inspection. gc.ca/plant-health/plant-pests-invasive-species/insects/spotted-lanternfly/eng/1433365581428/1433365581959 (accessed on 7 December 2020). 
67. Rott, M.; Johnson, R.; Masters, C.; Green, M. First report of Bois Noir phytoplasma in grapevine in Canada. Plant. Dis. 2007, 91, 1682. [CrossRef] [PubMed]

68. Olivier, C.; Saguez, J.; Stobbs, L.W.; Lowery, D.T.; Galka, B.; Whybourne, K.; Bittner, L.; Xiensheng, C.; Vincent, C. Occurrence of phytoplasmas in leafhoppers and cultivated grapevines in Canada. Agric. Ecosyst. Environ. 2014, 195, 91-97. [CrossRef]

69. Wallingford, A.K.; Fuchs, M.F.; Martinson, T.; Hesler, S.; Loeb, G.M. Slowing the Spread of Grapevine Leafroll-Associated Viruses in Commercial Vineyards with Insecticide Control of the Vector, Pseudococcus maritimus (Hemiptera: Pseudococcidae). J. Insect Sci. 2015, 15, 112. [CrossRef]

70. Poojari, S.; Boulé, J.; DeLury, N.; Lowery, D.T.; Rott, M.; Schmidt, A.-M.; Úrbez-Torres, J.R. Epidemiology and Genetic diversity of Grapewine leafroll-associated Viruses in British Columbia. Plant Dis. 2017, 101, 2088-2097. [CrossRef]

71. Fall, M.L.; Xu, D.; Lemoyne, P.; Ben Moussa, I.E.; Beaulieu, C.; Carisse, O. A Diverse Virome of Leafroll-Infected Grapevine Unveiled by dsRNA Sequencing. Viruses 2020, 12, 1142. [CrossRef]

72. Jones, G.V.; White, M.A.; Cooper, O.R.; Storchmann, K. Climate change and global wine quality. Clim. Chang. 2005, 73, 319-343. [CrossRef]

73. Jones, G.V.; Alves, F. Impact of climate change on wine production: A global overview and regional assessment in the Douro Valley of Portugal. Int. J. Glob. Warm. 2012, 4, 383-406. [CrossRef]

74. Hannah, L.; Roehrdanz, P.R.; Ikegami, M.; Shepard, A.M.; Shaw, M.R.; Tabor, G.; Zhi, L.; Marquet, P.A.; Hijmans, R.J. Climate change, wine, and conservation. Proc. Natl. Acad. Sci. USA 2013, 110, 6907-6912. [CrossRef] [PubMed]

75. Teslić, N.; Ricci, A.; Parpinello, G.P.; Versari, A. Vitis vinifera facing climate change. Am. J. Enol. Vitic. 2019. N. 11/1. Available online: https:/ / www.infowine.com/intranet/libretti/0/18240-1907-Teslic-Enoforum2019-presentazione-artEN.pdf (accessed on 17 August 2021).

76. Santos, J.A.; Fraga, H.; Malheiro, A.C.; Moutinho-Pereira, J.; Dinis, L.-T.; Correia, C.; Moriondo, M.; Leolini, L.; Dibari, C.; Costafreda-Aumedes, S.; et al. A Review of the Potential Climate Change Impacts and Adaptation Options for European Viticulture. Appl. Sci. 2020, 10, 3092. [CrossRef]

77. Roy, P.; Grenier, P.; Barriault, E.; Logan, T.; Blondlot, A.; Bourgeois, G.; Chaumont, D. Probabilistic climate change scenarios for viticultural potential in Québec. Clim. Chang. 2017, 143, 43-58. [CrossRef] 